\title{
Legal Regulation and Reflection of Public Health Emergencies in China on the Example of Coronavirus Pandemic
}

\section{Regulacje prawne w kontekście sytuacji kryzysowych związanych ze zdrowiem publicznym w Chinach na przykładzie pandemii koronawirusa}

\author{
Lei Song \\ School of Marxism, Beijing Institute of Technology \\ 100081, 5 Zhongguanchun nan Str., People's Republic of China
}

\begin{abstract}
At the moment, the shortcomings in the system of responding to crises in the health sector lie in the imperfection of the response order and management mechanisms. The purpose of the paper is to investigate the legal regulation and reflection of public health emergencies in China, as exemplified by the case of 2019 coronavirus. The paper discusses the legal framework for the regulation of emergency situations in public health in China for the period from the end of 2019. The importance of preventing and controlling the epidemic is substantiated, and shortcomings in the work to combat the epidemic are analysed. Particular attention is paid to issues of informing the public and the rule of law in emergency situations in public health. The provisions of the legislation of the People's Republic of China in public health emergencies were also examined. The paper is of practical importance not only for China, but for the entire world in the prevention and control of coronavirus.
\end{abstract}

Key words: emergency management, infectious diseases, new coronavirus, epidemic

\section{Streszczenie}

Niedociągnięcia systemu reagowania na kryzysy w sektorze zdrowia tkwią w niedoskonałości kolejności reagowania i mechanizmów zarządzania. Celem artykułu jest zbadanie regulacji prawnych i odzwierciedlenie sytuacji kryzysowych w zakresie zdrowia publicznego w Chinach, na przykładzie epidemii koronawirusa z 2019 r. W artykule omówiono ramy prawne regulowania sytuacji nadzwyczajnych w zdrowiu publicznym w Chinach. Udokumentowano znaczenie zapobiegania i kontrolowania epidemii oraz przeanalizowano niedociągnięcia podczas zwalczania epidemii. Szczególną uwagę zwrócono na kwestie informowania opinii publicznej i praworządności w sytuacjach nagłych zdarzeń odnoszących się do zdrowia publicznego. Przeanalizowano również przepisy Chińskiej Republiki Ludowej dotyczące sytuacji kryzysowych związanych ze zdrowiem publicznym. Artykuł ma praktyczne znaczenie w zapobieganiu i kontroli koronawirusa nie tylko dla Chin, ale dla całego świata.

Słowa kluczowe: zarządzanie kryzysowe, choroby zakaźne, nowy koronawirus, epidemia

\section{Introduction}

In the history of humankind, infectious diseases have always been a major threat to human health. The spread of infectious diseases has had a major impact on human civilisation. That is why the countries of the world are taking appropriate measures and creating tools to strengthen legislation in health, to control the spread of infectious diseases, environmental health, and health education (Tongda, 2004). At present, the legislative provisions in healthcare in many countries, from the standpoint of 
the laws of regulation themselves and other areas, vary widely from state to state. However, ensuring the health and prosperity of citizens has always been one of the priority tasks of the state. Based on the interests of strengthening the legislative framework in public health, establishing unified fundamental principles of legislation in healthcare, the legislative model of each state includes: the economic model (Havighurst, 1988), the model of trust (Hall, 2002), the salvation model (Bloche, 2003), the model of international health right (Mariner, 2009), a model of social justice Rosenblatt, 1988), and a model of healthy justice (Wiley, 2016).

Prior to the SARS outbreak, Chinese health legislation was rather backward. The results of studies of that time indicate that the scientific community approached the study of emergency legislation, state laws on a state of emergency, and legislation on emergency situations (Jihong, 1994). After the outbreak of SARS, academics began hard work on research in public health. However, scientists investigated the system of legislation on public health crises within the legal system of emergency situations, did not separate the two systems (Huaide, 2004). It is the lack of order in the Chinese public health system that is its biggest problem. In this regard, a significant part of the Chinese healthcare system is incapable of functioning properly (Chi-Man Yip, 2012). In recent years, Chinese health legislation has been constantly improved, and the government is making efforts to provide basic healthcare (Yunliang, 2014). As health laws and their enforcement remain unresolved, this leads to the need to continue to work on improvement of the public health crisis response system (Jianyang, 2003). Despite the use of the organisation form of the US Centres for Disease Control and Prevention (CDC), the similar Chinese Centre for Disease Control and Prevention (CCDC) cannot get rid of the functions of a research institution. Such a distribution of powers is insufficient, and this leads to the fact that mechanisms for controlling the spread of diseases in China cannot respond well to the emergence of new infectious diseases (Weikang, 2003). At the same time, with a lack of an authoritative coordinating body, ambiguity appears in the job functions of other departments. When resolving largescale public health crises due to the impossibility of creating effective mechanisms, it is possible to miss the right moment of response to an emergency situation in healthcare, thereby aggravating the problem (Peng, 2007). Furthermore, the right to information is one of the fundamental rights of citizens, and timely and accessible reporting by the authorities ensures that this right is respected. Protecting citizens' right to information is a core value of government transparency (Ji, 2013).

\section{Specific features of emergency legislation in pub- lic health}

From the end of December 2019, patients with a diagnosis of pneumonia of unknown origin began to continuously turn to hospitals in Wuhan. In Wuhan, the influenza epidemic continued to spread, with 27 patients diagnosed with viral pneumonia. On December 31, 2019, the National Health Commission of the PRC (NHC) sent the first group of specialists to Wuhan to conduct research (Wei, 2019). On January $1,2020,8$ people were prosecuted for misinformation about the so-called Wuhan virus (Jun, 2020) On January 5, 2020, the Wuhan Health Commission (WHC) stated that people with previously unknown pneumonia are sellers in the Huanan seafood market. The initial investigation did not reveal any transmission of the virus from person to person, as no cases of infection of medical workers were detected. Infection with influenza, bird flu, adenovirus, SARS, and Middle Eastern respiratory syndrome (MERS) were also ruled out (Changzheng, 2020). On January 18, a second group of specialists from the Health Commission arrived in Wuhan, confirming the transmission of the virus from person to person, and recommended quarantining the city (Nanshan, 2020). On January 20, 2020, NHC issued Order No. 1 of 2020 on the inclusion of a new type of coronavirus in category B of the Law on the Prevention and Treatment of Infectious Diseases of the PRC with the recommendation of preventive measures for category A viruses (Jianhua, 2020). On January 23, 2020, Wuhan's public transport was suspended, airfields and stations were closed (Tintin, 2020). On January 30, by decision of the World Health Organization, a new type of coronavirus was included in the list of global health problems. After an outbreak of SARS 17 years ago, this epidemic disturbed both the people of China and the entire world.

Currently, the PRC legislation on public health emergencies includes the following provisions:

- Two laws: The Law on the Prevention and Treatment of Infectious Diseases of the PRC (came into force on December 1, 2004, amendments of June 29, 2013); The PRC Emergency Response Act (came into force on November 1, 2007).

- Administrative rule: Rules for responding to emergency situations in public health (came into force on May 9, 2003, amendments of January 8,2011 ).

- Two regulations: General Emergency Response Plan (came into force on January 8, 2006); Public Health Emergency Response Plan (came into force on February 26, 2006).

According to Section 3 of the PRC Emergency Response Act (hereinafter: the Response Act), an emergency is a natural disaster, a sudden catastrophe, a 
public health problem, or a public safety incident that suddenly arises and constitutes a public threat security. In the General Emergency Response Plan (hereinafter: the General Response Plan), the definition of an emergency is approximately the same as in the Response Act. Based on Article 2 of the Public Health Emergency Response Rules (hereinafter: the Response Rules), public health emergencies are called epidemics of infectious diseases that create or can cause serious harm to public health, mass diseases for unknown reasons, large-scale food poisoning, and other massive health problems. The Public Health Emergency Response Plan (hereinafter: the Response Plan) was approved based on the Law on Prevention and Treatment of Infectious Diseases of the PRC (hereinafter: the Law on Prevention). The Health Action Plan uses roughly the same wording as the definition of a public health emergency $R e$ sponse Rules.

The Response Act, the General Response Plan, the Response Rules and the Response Plan provide precise definitions of an emergency and an emergency in public health. They suggest that emergencies are described by urgency and the presence of a threat to public health. The epidemic of the new coronavirus corresponds to the legally defined features of a public health emergency.

\section{Public health emergency information survey}

On December 31, 2019, the first group of NHC specialists arrived in Wuhan. On January 3-5, WHC continued to publish information on the outbreak of the disease, the number of people with SARS by January 5 reached 59 people. The report said that there were no cases of transmission of the disease from person to person, there were no cases of infection of medical personnel. The report of January 5 also indicated the time of the emergence of the virus - the period from December 12 to 29 . On the same day, the Fudan University Clinical Centre for Public Health published a study of the genome of the new Wuhan virus, found its similarity to SARS equating to $89.11 \%$, suggested that the virus is transmitted through the respiratory tract. The Centre also recommended taking appropriate preventive measures in public places. On January 6 , the Control Centre included the Wuhan outbreak in the second category of response to public health problems. On January 18 , the second group of NHC specialists arrived in Wuhan, confirming the possibility of transmission of the disease from person to person.

On January 22, the Hubei Provincial Administration included the outbreak in a second category of health problems. On January 24, the level of response was increased to the first level. On January 27 afternoon, during an interview with the mayor of Wuhan, Zhou Xianwan, said that the outbreak of the epidemiological situation was not timely. Since this is an infectious and contagious disease, information about it must be made public in accordance with the Law on Prevention and Treatment of Infectious Diseases: As a representative of the local administration, after I get permission to make the information public, I will (Ting, 2020). According to Section 4, Chapter 1 of the Prevention Act, for infectious atypical pneumonia of class $\mathrm{B}$, anthrax pneumonia, highly pathogenic avian influenza transmitted between people, it is necessary to take control and prevention measures as for class A diseases.

Other infectious class B diseases and outbreaks of viruses of unknown origin also require control and prevention measures as a class A disease, but publishing information about them or taking any real action is allowed only after the approval of the administrative departments of the Department of Health Management of the State Council of the PRC. Thus, the authorities of provinces, special autonomous regions, cities of central subordination have the right to publish information and take measures in respect of class $\mathrm{B}$ or $\mathrm{C}$ infectious diseases that are common in this region, and must also inform the services of the public health department of the State Council of the PRC. Based on paragraph 3 of Article 1 of the Response Rules, depending on the nature, degree of danger and coverage, health emergencies are divided into especially serious (1st category), serious (2nd category), fairly serious (3rd category), and ordinary (4th category).

Clause 1 of Article 4 determines that at the time of an emergency in public health, local governments of different levels, in accordance with the principles of a phased response, develop a response plan of different levels. Article 3 states that emergency situations in public health below a particularly serious level should be decided by local authorities under their responsibility.

In reality, the Hubei provincial government could declare the second level of a public emergency on January 6, however, until January 22, after the NHC specialists confirmed the contagiousness of the virus, the second level of a public health problem was announced. However, the head of the local administration in Wuhan, during an interview with the media, confirmed that the knowledge of local authorities on emergency response laws in healthcare was weak, there were separate problems of bureaucracy and red tape.

\section{Description of the rule of law principle in emer- gencies}

On December 30, 2019, at 5 p.m., an ophthalmologist at the Wuhan Central Hospital, Li Wenliang, in a Wechat chat of the 4 clinical group of the University of Wuhan, published a message There are 7 cases of SARS registered in the Huanan seafood market and urged his colleagues to take action. To confirm his words, Li Wenliang published in the chat about a positive SARS test result with a high level of 
analysis accuracy in the patient, an attached a scan of his chest. An hour after that, he wrote in the chat that the information about the coronavirus was confirmed and is in the process of typing. On January 3, 2020, Li Wenliang was officially reprimanded by the police for spreading false rumours on social networks.

On January 8, 2020, Li Wenliang, during a patient examination, became infected with a new coronavirus of unknown origin. On January 10, 2020, Li Wenliang showed symptoms of fever and cough the disease progressed. On February 1, at 10 hours 41 minutes, Li Wenliang posted information on his Wechat account, claiming that he was tested positive for coronavirus. On February 7, 2020 at 258 a.m., an ophthalmologist at the Wuhan Central Hospital died after fighting a new type of coronavirus. On February 7, 2020, having received the Central Committee's approval, the Central Commission for Discipline Inspection decided to go to Wuhan to conduct a thorough investigation in response to the public reaction to the history of Dr. Li Wenliang (Baike, 2020). However, Dr. Li Wenliang, who was the first to sound the alarm about the outbreak of the virus, received no apology either from the Wuhan City Police or senior officials from Hubei Province regarding his censure. After the death of Li Wenliang, he was popularly called the whistle-blower of the virus. According to Article 19 of the Response Rules, the state establishes a warning system in case of emergency. The Main Department of Health of the State Council of the PRC established a reporting standard for emergency response and defined an alert system in case of an epidemic. In the presence of one of the following circumstances, the governments of the provinces, autonomous regions, and cities of central subordination must submit a report to the Head Department of Health of the State Council of the PRC within an hour after the emergency:

- on detection and spread of infectious diseases;

- on mass disease with an unexplained cause;

- on the emergence or possibility of the emergence of a previously disappeared strain of an infectious disease;

- $\quad$ on mass food poisoning, poisoning or disease in the workplace. The Main Department of Health of the State Council of China shall be obliged to report to the State Council on incidents that pose a threat to human health.

Based on Article 20 of the Response Plan, emergency control bodies, healthcare institutions and other relevant bodies, upon detection of an incident described in Article 19 of the said document, must report to the health department of the local county administration within 2 hours; the health department of the local administration must send a report to the local administration within 2 hours, as well as prepare a report for the higher department of health and for the department of health of the State Council of the PRC. After receiving the report, the county administration must submit the report to the higher municipal government or other higher administration within 2 hours; after receiving the report, the municipal administration must within 2 hours submit a report to the provincial government, autonomous region, city of central subordination.

According to paragraph 1 of Article 291 of the Criminal Code of the PRC (adopted on October 1, 1997, amended on November 4, 2017) (hereinafter referred to as the Criminal Code), the dissemination of fabricated information and misinformation on emergencies, epidemics, disasters, incidents in social networks and other media, or deliberate dissemination of information that violates the peace of citizens in social networks and other media shall be punishable by imprisonment for up to three years, short-term imprisonment, or supervision. With serious consequences - for a period of 3 to 7 years. According to Article 25 of the PRC Law On Penalties for Violations of Public Order (adopted on March 1, 2006, amendments of January 1, 2013) (hereinafter On Penalties for Violations), rumours, dubious reports of disasters, epidemics, incidents, and other methods of disturbing public peace shall be punishable by arrest for a period of 5 to 10 days or a fine of up to 100 yuan; either by arrest up to five days or a fine of up to 500 yuan, depending on the gravity of the crime. In the case of 8 Internet users fined by Wuhan police for spreading rumours of Wuhan Pneumonia, the law was taken literally. Indeed, the reported cases of pneumonia were not related to SARS, and, therefore, the dissemination of information about the detection of SARS in Wuhan fell under the article on the dissemination of misinformation that violates public peace, and accordingly, administrative or criminal penalties for such actions were legitimate. However, in reality, although the new pneumonia is not SARS, disease information has not been completely fabricated. If the rumour had spread, preventive measures would have been taken in time - wearing masks, strict disinfection, avoiding wildlife markets, which would help to contain and control the spread of the virus. Therefore, law enforcement agencies must take into consideration the presence of malicious intent and the degree of awareness in the issue of those publishing and disseminating information. If, nevertheless, the information at large is reliable, and the publishers and disseminators of it do not have malicious intent, and their actions do not cause obvious harm, such misinformation should be treated more tolerantly and gently.

Misinformation arises from untimely publication of information that is difficult for the public to understand. A natural consequence of emergencies is the concern of citizens about their health. With timely notification and proper informing of the population about the current situation, panic naturally decreases. Otherwise, the population turns to social networks 
for information, listens to rumours. Thus, the solution to the problem of spreading rumours lies not in punishing the perpetrators after the fact, but in correctly informing the population. If the government does the job of publishing information, the masses will begin to compare open information and false rumours received, and over time they will find that information from the government is timely and accurate, and false rumours will lose massive support. And vice versa, if false rumours get confirmation over and over again, in a critical situation the masses will naturally choose to believe the rumours. Based on this logic, if there is a threat to public health, governments of different levels are required not only to be responsible for informing at the local level, but also to think about national security.

It is undeniable that the modern media climate has radically changed since SARS. In the days of SARS, there was no alternative media (WeMedia), official information channels were the only source. At that time, although there were unconventional ways of disseminating information, namely forums, blogs, messengers, their influence was limited, and they did not claim to be the main source of information. To date, the situation has changed significantly. Along with the development of commercial media, a number of social networks have also appeared such as Weibo, Wechat, acting both as alternative sources of information and as a platform for expressing personal opinion. People in the epidemic zone communicate through voice messages, short videos, and using other formats, establishing direct and reliable contact and undermining the leadership of conventional media in disseminating information. It is obvious that with a large amount of information, any attempt to conceal the facts is in vain; conventional measures to control information are very difficult to implement. On the one hand, it is an indicator that Chinese society has become even more mature, free, and open. On the other hand, this freedom provided the media basis for the dissemination of false information. This is the first time that the free media climate has faced a major public health problem. This subject is complex and relevant, and should be addressed in the context of modern government of a state.

\section{Specifics of pressure on public opinion in public health emergencies}

An important detail of the Li Wenliang Case is the official censure expressed by the police department on Zhongnanlu Street, Wuhan District, Wuhan City. In the document of the Zhongnanlu Wuhan Police Department (20200103), the word censure is used twice - once in the title of the published censure verdict, the second time - in the text of the document: based on current legislation, you are censured for posting information on social networks that does not correspond to reality. The Modern Chinese Dictionary defines the word censure as a measure of public punishment by criticism, defined by the people's court as a punishment for a light crime or misconduct. This word can also serve as a verb with the meaning - instruct and warn (Dictionary of Modern..., 2005).

From the standpoint legal science, the excess of powers prescribed by law is not allowed, the actions of state bodies should be regulated by law. The current law on Administrative Offenses (adopted on October 1, 1996, amendments of September 1, 2017) does not mention censure as a preventive measure that law enforcement bodies can take. From the standpoint of administrative law, this measure actually emerged in Article 9 of the Rules of Punishment in the Control of Public Order of the People's Republic of China, which were no longer in force since 2006 (came into force on January 1, 1987, and lost legislative force on March 1, 2006). However, this Article was applied to minors over 14 years old. The said Article stipulates a milder sentence for persons under the age of majority: persons under the age of 14 who have committed an offense are exempted from punishment, but may receive public censure, and their guardians should educate them in strictness. Accordingly, censure as a measure of administrative punishment of the district police station on Zhongnanlu Street, Wuhan City, Wuhan City, regarding the doctor, contradicts the essence of the legislative power and the power of amendments to Article 7 of the Law on the Legislative Power of the People's Republic of China (came into force on July 1, 2000, amendments of 15 March 2015).

In the modern Chinese legislative system, whether substantive or procedural, censure constitutes a preventive measure that a people's court can choose. Article 37 of the Criminal Code states that for minor offenses, a sentence is not required, criminal penalties can be dispensed with, however, based on various circumstances of the case, public censure or a written remorse, apology, compensation for damages, as well as an administrative punishment or a penalty can be imposed. Section 2 of Article 193 of the Code of Criminal Procedure of the People's Republic of China (came into force on January 1, 1980, amendments of October 26, 2018) states that witnesses who refuse to attend the court without good reason or who refuse to speak after being present in the court may receive public censure, under aggravating circumstances, the judge may sentence them to 10 days of arrest. Clause 2 of Article 65 of the Code of Civil Procedure of the People's Republic of China (came into force on April 9, 1991, amended on June 27, 2017) states that the people's court determines the certificates that must be provided in accordance with the statements of the parties, as well as the deadlines for submission. 
In case of untimely provision of evidence, the court may require an explanation of the reasons for the delay; in the absence of grounds or inability to establish the reasons for being late, the court may not accept the evidence or accept it, but express a censure or impose a fine. Clause 2 of Article 110 states that a people's court may express a censure, remove them from the courtroom, or impose a fine on individuals who violate the rules of the court. Article 59 of the Code of Administrative Procedure of the PRC (adopted on October 1, 1990, amended on June 27, 2017) states that in case of a series of actions by the parties to the proceedings or by other persons, the people's court may, depending on extenuating and aggravating circumstances, apply the following sanctions to them - express public censure, order written repentance, impose a fine of up to 10 thousand yuan, or arrest for up to 10 days. If there is a corpus delicti, criminal prosecution is also possible. Thus, the powers of the people's court include both the imposition of criminal penalties for people with minor violations of the rules and the application of sanctions against violators of the judicial procedure. Furthermore, the censure of the doctors was justified as follows: In connection with your violation of the provisions of the 'Rules of Punishment in the Control of Public Order of the PRC' and a serious violation of public peace, your actions were regarded as criminal". It is unclear from the cited text, the violation of which law is referred to, only mysterious provisions are mentioned, without a specific reference to the article of legislation. In this case, the principle of the legality of administrative actions was violated.

However, despite the fact that the police officers performed their duties in accordance with the legislation, it later turned out that the warnings of $\mathrm{Li}$ Wenliang and his fellow doctors were well-founded, which provoked a wave of public outrage. Thus, the Wuhan government should openly admit its mistakes, paying tribute to Li Wenliang and his 8 colleagues. Article 2 of the PRC Constitution (adopted on December 4, 1982, amended on March 11, 2018) states that all power in the PRC belongs to the people. The people are the starting point for all politics, economics, social activities in China. However, citizens do not learn information from legal acts or political propaganda. They learn about state affairs through major and minor incidents in their own lives, this is the way they learn the connection between the people and political power (Xijin, 2020). Article 35 of the PRC Constitution states that the Chinese people have the right to freedom of speech, press, assembly, and movement. Article 51 states that citizens of the PRC in the exercise of their rights and freedoms must not interfere with state, public, and collective interests, as well as the legal rights and freedoms of other citizens.

The publication of public censure by Li Wenliang caused a significant public outcry. It is important to note that there was no corpus delicti in the doctor's actions - he only warned people of his professional circle about the danger of infection. When the epidemic spread from Wuhan to Hubei, and then throughout China, it was acknowledged that $\mathrm{Li}$ Wenliang was right and that he was unjustly treated. However, the Wuhan government did not take public opinion into consideration and did not withdraw the censure, avoiding this issue until the media boiled with indignation and more and more moved away from the people. On February 5, 2020, Chairman Xi Jinping, during a speech at the third meeting of the commission on ensuring the rule of law in public administration, emphasised that at the time, in conditions of a significant threat to sanitary and epidemiological well-being, it was necessary to create a favourable legal environment for organising preventive measures and combating the spread of the virus (Jinping, 2020). 76 days after Li Wenliang's censure, on March 19, 2020, the Wuhan City Public Security Authority decided to cancel the censure verdict and solemnly apologised to the doctor's family and brought the perpetrators to administrative responsibility.

\section{Conclusions}

Proceeding from the foregoing, it can be argued that among the legitimate ways to respond to a sudden outbreak of infection are:

- Strict implementation of the prevention and control of the epidemic, as well as compliance with emergency laws. It is necessary to take strict measures for prevention and control in accordance with the law, to inexorably prevent the spread of the epidemic.

- Strict implementation of the articles of the Law on Prevention, in accordance with the law, taking measures to control and prevent the epidemic.

- In accordance with the law, raise public awareness of the epidemic. Provision of information about the epidemic in accordance with law-approved content, order, format, time frame, and accuracy.

- Tightening judicial control in key areas for epidemic control, and ensure justice.

- Ensuring the rule of law in matters of prevention and control of the epidemic, informing the public.

- Ensuring the resolution of legal issues during the fight against the epidemic, providing legal aid to citizens in need.

Acknowledgement. This paper is an interim research result of a theoretical model of reform ideological and political programs in Universities of Beijing (Beijing Institute of Technology) and the Innovation center for theoretical studies of socialism with Chinese characteristics in the Universities of Beijing (Beijing University of Technology). 


\section{References}

1. TONGDA S., 2004, Studies on lessons from public health emergency and corresponding strategies, Zhejiang University, China: 201.

2. HAVIGHURST C., 1988, Health care as a laboratory for the study of law and policy, Journal of Legal Education, 38(3): 499-504.

3. HALL M., 2002, Law, medicine and trust. Stanford Law Review, 55(2): 463-527.

4. BLOCHE M., 2003, The invention of health law, California Law Review, 91(2): 247-322.

5. MARINER W., 2009, Toward and architecture of health law, American Journal of Law and Medicine, 35: 67-87.

6. ROSENBLATT R., 1988, Conceptualizing health law for teaching purpose: The social justice perspective, Journal of Legal Education, 38(4): 489-497.

7. WILEY L., 2016, From patient rights to health justice: Securing public's interest in affordable, highquality health care, Cardozo Law Review, 37(3): 833889.

8. JIHONG Mo., 1994, Foreign emergency legal system, Law Press, China: 11.

9. HUAIDE Ma., 2004, Jurisprudential thinking of emergency response, China University of Political Science and Law Press, China: 78-84.

10. CHI-MAN YIP W., 2012, Early appraisal of China's huge and complex health-care reforms, The Lancet, 379: 833-842.

11. YUNLIANG Ch., 2014, Research on the legalization of basic medical services, Science of Law, 2: 73-85.

12. JIANYANG X., 2003, Thinking about SARS magnitude outburst public health incident, in: Medicine \& Philosophy, 24(6): 15-16.

13. WEIKANG D., 2003, Gusty public health affair to deepen reform of medical service system's apocalypse, Chinese Primary Health Care, 9: 13-15.

14. PENG X., 2007, Study on standardization and sustaining system of dealing with public health emergency in China, Fudan University, China: 6.

15. JI Y., 2013, The legal norms of government information disclosure must change perspectives-with the aim of protecting citizens' right to know, Political Science and Law, 2: 116-124.

16. WEI L., 2019, In December, there were 27 cases of new pneumonia in Wuhan, http://m.news.cctv.com/ 2019/12/31/ARTIL1JxT1xYZ9uMgxwJRDmJ19123 1.shtml.

17. JUN L., 2020, 8 people were prosecuted for spreading rumours about 'Wuhan pneumonia' on the Internet, http://www.xinhuanet.com/legal/2020-01/01/c_ 1125412773.htm

18. CHANGZHENG L., 2020, The government of Wuhan reported 59 cases of the new virus, http://www. xinhuanet.com/local/2020-01/05/c_1125424181.htm ?baike.

19. NANSHAN Z., 2020, About the epidemic, Tencent News, https://new.qq.com/omn/20200205/20200205 A0ID8300.html

20. JIANHUA W., 2020, The Chinese health Commission issued order No 1, Xinhua, http://www. xinhuanet.com/politics/2020-01/21/c_1125488596. htm.

21. TINTIN G., 2020, Wuhan is preparing for war, Renminwang, http://society.people.com.cn/n1/2020/ 0123/c1008-31561279.html.

22. Law on the prevention and treatment of infectious diseases of the PRC, http://www.gov.cn/banshi/200508/01/content_19023.htm.

23. Emergency response law of the people's Republic of China, http://www.gov.cn/ziliao/flfg/2007-08/30/ content_732593.htm.

24. Rules for responding to public health emergencies, http://www.gov.cn/gongbao/content/2011/content_ 1860801.htm.

25. The General plan of response in case of emergencies, http://www.gov.cn/jrzg/2006-01/08/content_150878. htm.

26. Plan of response in case of health emergencies, http://www.gov.cn/yjgl/2006-02/26/content_211654. htm.

27. TING, 2020, Wuhan time: 20 days from the closing of the city, Economic Observation Network, http://www.eeo.com.cn/2020/0207/375826.shtml.

28. BAIKE B., 2020, Li Wenliang, https://baike.baidu. com/item/\%E6\%9D\%8E\%E6\%96\%87\%E4\%BA\% $\mathrm{AE} / 24300481$.

29. Law of the people's Republic of China 'On penalties (penalties) for public order violations', http://www. gov.cn/ziliao/flfg/2005-08/29/content_27130.htm.

30. Dictionary of Modern Chinese language, 2005, Commercial Press, China: 1554.

31. XIJIN H., 2020, The masses are outraged, those who outraged them must pay, Global Time, https://baijiahao.baidu.com/s?id=1657869396868285317\&wfr=s pider\&for $=\mathrm{pc}$.

32. Constitution of the people's Republic of China, http:// www.gov.cn/guoqing/2018-03/22/content_5276318. htm.

33. JINPING X., 2020, Speech at the third meeting of the Commission on law enforcement in public administration, People's Daily, http://cpc.people.com.cn/ n1/2020/0206/c64094-31573224.html. 